\title{
Bactris Setosa Mart. (Tucum-do-cerrado) Aqueous Extract Increases Growth and Viability in Saccharomyces Cerevisiae BY4741 and YAP1 $\Delta$ Under Stress Caused by Menadione and Hydrogen Peroxide
}

Renata Silva ( $\square$ nutrsilva@gmail.com )

Universidade de Brasilia https://orcid.org/0000-0001-9454-9704

Élida Geralda Campos

Universidade de Brasilia

Research Article

Keywords: yeast growth, polyphenols, fruit, bioactive compounds

Posted Date: March 30th, 2021

DOI: https://doi.org/10.21203/rs.3.rs-350535/v1

License: (c) (i) This work is licensed under a Creative Commons Attribution 4.0 International License.

Read Full License 


\section{Abstract}

Yeast cells from Saccharomyces cerevisiae can increase endogenous antioxidant response when stressed to prevent cell death. YAP1 is a transcription factor responsible to activate genes that encoding antioxidant enzymes such as superoxide dismutase and catalase and can be an important key to protect these cells. Tucum-do-cerrado (Bactris setosa Mart.) is a Brazilian fruit rich in polyphenols and bioactive compounds mainly found in the peel. This study investigated cell growth and viability using $S$. cerevisiae wild type and yap $1 \Delta$ strains exposed to tucum-do-cerrado peel aqueous extract and hydrogen peroxide $\left(\mathrm{H}_{2} \mathrm{O}_{2}\right)$ and menadione induced oxidative stress.

Yeast cells from BY4741 and yap1 $\Delta$ were exposed to different concentrations of tucum extract, menadione and hydrogen peroxide separated and together in mixed groups for $20 \mathrm{~h}$ and measured for growth curve. For colony survival yeast cells were exposed to these compounds for $72 \mathrm{~h}$ in ágar plates and colonies were counted. Results showed that aqueous extract of tucum-do-cerrado was capable to recover BY4741 density of cells stressed with both menadione and $\mathrm{H}_{2} \mathrm{O}_{2}$ but not for yap1 $\Delta$ strain.

Besides, higher concentrations of the extract demonstrated a delay in cell growth. Colony survival showed that the exposition to tucum extract resulted in colony recover in BY4741 yeast cells but not for mutant yap1 $\Delta$ strains which maintained low viability even with high extract concentration. In conclusion, despite $S$. cerevisiae antioxidant response to menadione and $\mathrm{H}_{2} \mathrm{O}_{2}$ is different, the protection afforded by tucum extract in $\mathrm{H}_{2} \mathrm{O}_{2}$ stressed cells, is probably through an YAP1 pathway.

\section{Introduction}

Saccharomyces cerevisiae antioxidant response is carried out through several mechanisms, including metaloproteins, which protect the cells from iron and copper toxicity, and the product of the CUP1 gene, which protects cells against menadione-induced stress. S. cerevisiae also has cytoplasmic membranes with high content of saturated fatty acids, that are more resistant to lipid peroxidation, and vitamin $\mathrm{C}$, both of which may provide an efficient protection from stress[1]. Yeast cells have both, enzymatic and non-enzymatic antioxidant systems[2]. The main enzymes are superoxide dismutase (SOD), catalase and peroxidases, such as cytochrome c peroxidase and glutathione peroxidase (GPX). The non-enzymatic defense system includes scavenger molecules such as glutathione[3].

Another key mechanism used by yeast against oxidative stress is regulation of the endogenous antioxidant system by transcription factors. While in animal cells this mechanism mainly involves the transcription factor Nrf-2 (NF-E2-related factor 2), that activates genes that encoding antioxidant enzymes[4], S. cerevisiae has the transcription factor YAP1 (Yeast Activator Protein 1) that plays similar role when cells face oxidative stress situations. Yeast cells have sensors that detect low levels of hydrogen peroxide and activate the thioredoxin and glutathione pathways, which activate YAP1, this process is known as antioxidant and redox signaling[5]. YAP1 activation occurs by its nuclear export regulation and this process is mainly mediated by Chromosomal Maintenance 1 (Crm1), also known as Exportin 1, which exports YAP1 to the cytoplasm in normal conditions[6]. However, under stress 
conditions both cysteine-rich domains located in $\mathrm{N}$ and $\mathrm{C}$ terminal parts of the YAP1 protein constitute disulfides between the $\mathrm{N}$-terminal Cys303 and the $\mathrm{C}$-terminal Cys598, mainly in response to oxidation caused by hydrogen peroxide $\left(\mathrm{H}_{2} \mathrm{O}_{2}\right)$. As a result of this structural change, interaction between YAP1 and Cmr1 is inhibited, which causes the nuclear accumulation of YAP1 and its consequent activation[7].

A decrease in cellular growth can be used by yeast as a physiological response to prevent oxidative stress caused by molecules such as $\mathrm{H}_{2} \mathrm{O}_{2}$ and menadione[8]. It has been shown that menadione increases $\mathrm{H}_{2} \mathrm{O}_{2}$ production and it is responsible for the generation and accumulation of reactive oxygen species (ROS), that affect the morphology and viability of yeast cells $[9,10]$.

Tucum-do-cerrado (Bactris setosa Mart.) is a Brazilian fruit and is known for its antioxidant properties in vitro and in vivo[11,12]. The fruit has bioactive compounds such as vitamin $\mathrm{C}$, quercertin, catechin, peonidin, anthocyanins and flavonoids, mainly found in the peel, that also showed major antioxidant activity in vivo and in vitro when compared to the pulp[11-16]. It is not known if these compounds can influence yeast cell growth and the YAP1 pathway. Therefore, the aim of this study was to evaluate cell growth and viability using a $S$. cerevisiae strain that is unable to express YAP1 and the correspondent wild type strain exposure to tucum-do-cerrado peel aqueous extract and $\mathrm{H}_{2} \mathrm{O}_{2}$ and menadione induced oxidative stress.

\section{Material And Methods}

\subsection{Extract of tucum-do-cerrado}

Fruits were obtained from a local merchant from "Fazenda Grama", Teresópolis de Goiás - GO/Brazil. Fruits were washed with distilled water and peel was manually removed and lyophilized. For preparation of the crude aqueous extract, $1 \mathrm{~g}$ of pulverized peel was mixed with $10 \mathrm{ml}$ of distilled water. The contents were shaken for $16 \mathrm{~h}$ at $4^{\circ} \mathrm{Cand}$ filtered through a $0.22 \mu \mathrm{m}$ filter. The aqueous extract was stored in a -20 ${ }^{\circ} \mathrm{C}$ freezer until use.

\subsection{Yeast strains}

S. cerevisiae cells wild type BY4741 (MATa his3 leu2 met15 ura3) and mutant yap1 $\Delta$ (wich doesn't contain the yap1 transcription factor) were used for growth and survival experiments. Strains were provided by Dr. Marcos Dias Pereira from Chemistry Institute of Federal University of Rio de Janeiro, Brazil.

\subsection{Cell culture and growth}

S. cerevisiae cells were maintained in Yeast extract, Peptone, Dextrose (YPD) medium composed by $1 \%$ yeast extract, $2 \%$ peptone, $2 \%$ dextrose and $2 \%$ ágar at $4{ }^{\circ} \mathrm{C}$. Yeast growth were performed in YPD liquid medium at $28^{\circ} \mathrm{C}$ and $200 \mathrm{rpm}$. Growth evaluation for further experiments was performed by optical density $\left(O D_{600}\right)$ at $600 \mathrm{~nm}$. 


\subsection{Yeast dry weight curve}

Inoculum for each yeast strain (BY4741 and yap1 1 ) were prepared using $50 \mathrm{ml}$ of YPD medium and 1 colony each strain. After $18 \mathrm{~h}$ incubation at $28^{\circ} \mathrm{C}$ and $200 \mathrm{rpm}, 2 \mathrm{ml}$ of inoculum was transferred to $2 \mathrm{ml}$ tubes previously weighed. Samples were centrifuged at $10.000 \mathrm{rpm}$ for $5 \mathrm{~min}$ at room temperature. The supernatant was discarded and yeast cells were heated at $60^{\circ} \mathrm{C}$ until reach stable weight. For number of cells $(\mathrm{mg} / \mathrm{ml})$

stable weight - inicial weight $=\frac{\text { final weight }}{\text { diluition }} \times 1.000$

were used. Diluitions of 20,25, 50 and 100 were made for each strains and absorbance readed in spectrophotometer at $600 \mathrm{~nm}$. Angular coefficient was calculated and used to adjust number of cells to be used on further analysis.

\subsection{Growth curve}

One inoculum for each yeast strain (BY4741 and yap1 1 ) were prepared using 10ml of YPD medium and 1 colony of each strain. After $18 \mathrm{~h}$ incubation at $28^{\circ} \mathrm{C}$ and $200 \mathrm{rpm}$, absorbance was at $600 \mathrm{~nm}$ and cells were adjusted to $40 \mu \mathrm{g} / \mathrm{mL}$ [17] in a final volume of $1 \mathrm{ml}$ for every experimental group. Two control groups were made, one just with yeast cells and medium and one added with $1 \%(\mathrm{v} / \mathrm{v})$ ethanol. Aqueous extract of tucum were added in several concentrations $(10,25,50,100$ and $150 \mu \mathrm{g} / \mathrm{ml})$, menadione ( 5 and 15 $\mu \mathrm{M})$ and hydrogen peroxide ( 0.5 and $1 \mathrm{mM})$ to form other experimental groups. These compounds were tested separated and together in mixed groups. Cells were plated at 96 well plates and growth measured each 30min during 20h at Synergy HTX Multi-Mode Microplate Reader $600 \mathrm{~nm}$. Data was collected on Gen5 software.

\subsection{Cell Viability}

Inoculum (BY4741 and yap1 1 ) were prepared using 10ml of YPD medium and 1 colony for each strain. After $18 \mathrm{~h}$ incubation at $28^{\circ} \mathrm{C}$ and $200 \mathrm{rpm}$, absorbance was measured at $600 \mathrm{~nm}$ and cells were adjusted to $40 \mu \mathrm{g} / \mathrm{mL}$ [17] in to a $5 \mathrm{ml}$ final volume for every experimental group. Aqueous extract of tucum were added at 50 and $150 \mu \mathrm{g} / \mathrm{ml}$ concentrations, menadione at $5 \mu \mathrm{M}$ and hydrogen peroxide at $0.5 \mathrm{mM}$ to form other experimental groups. Next, groups were incubated for $24 \mathrm{~h}$ at $28^{\circ} \mathrm{C}$ and $200 \mathrm{rpm}$ and after this time cells were washed with PBS buffer $x 1$, diluted in YPD medium at $10^{0}, 10^{-1}, 10^{-2}$ e $10^{-3}$ and $10 \mu \mathrm{l}$ plated in YPD medium solid $2 \%$ ágar $(\mathrm{w} / \mathrm{v})$ for each group. Plates were incubated in bacteriological incubator for $72 \mathrm{~h}$ at $28^{\circ} \mathrm{C}$. After this time colonies were counted and $10^{-3}$ dilution was used for analysis.

\subsection{Statistical Analysis}

Results are expressed as mean \pm SEM. Samples were compared using one-way analysis of variance (ANOVA) and the post hoc test of Bonferroni. For statistics significance, $P$-value $<0.05$ was used. Analysis 
were made by software GraphPad Prism v6. For yeast dry weight curve software Microsoft Excel was used.

\section{Results}

The yeast cell growth coefficient found in dry weight curve and used to calculate cell concentration for both yeast strains (BY4741 and yap1 $\Delta$ ) was 0.5 (not shown). Both yeast strains were exposed to stress with menadione and $\mathrm{H}_{2} \mathrm{O}_{2}$ in varied concentrations, as showed in Fig. 1, BY4741 strain stress were significative $(p<0.05)$ when exposed to $\mathrm{H}_{2} \mathrm{O}_{2}$ and decrease cell concentration in both strains were dose dependent demonstrating the potential to slow cell growth in addition to reduction of cell density after exposition time. All concentrations for both menadione and $\mathrm{H}_{2} \mathrm{O}_{2}$ had a significant impact $(p<0.05)$ on yap1 $\Delta$ strain cells. Ethanol $(1 \%)$ did not show potential to reduce growth. These results were used to select concentrations to further analysis.

When exposed to different concentration of tucum-do-cerrado extract (Fig. 2) cells from BY4741 and yap $1 \Delta$ were not significatively affected in cell density. In higher concentrations $(100$ and $150 \mu \mathrm{g} / \mathrm{ml})$ was observed a delay in cell growth. Results for menadione $(15 \mu \mathrm{M})$ and $\mathrm{H}_{2} \mathrm{O}_{2}(0.5 \mathrm{mM})$ induced stress show that cells with all tucum extract concentrations $(10,25,50,100$ and $150 \mu \mathrm{g} / \mathrm{ml})$ managed to recover cell density at the end (Fig. 3). Unlike wild type S.cerevisiae cells, yap1 $\Delta$ strain had a significative $(p<0.05)$ decrease in cell density for both stressors but did not recover when exposed to tucum extract in any tested concentrations (Fig. 3).

Colony count results showed first that cell viability on BY4741 and yap $1 \Delta$ were significatively reduced ( $p$ $<0.05$ ) at $15 \mu \mathrm{M}$ menadione and $0.5 \mathrm{mM} \mathrm{H}_{2} \mathrm{O}_{2}$ (Fig. 4) corroborating the result found in growth curves. When exposed to 50 and $150 \mu \mathrm{g} / \mathrm{ml}$ of tucum extract, BY4741 yeast viability was not affected but for yap1 $\Delta$ strain all concentrations of tucum extract significantly reduced colony viability (Fig. 4). However, the lowest concentration of tucum indicated a major effect in reducing mutant colony cells viability.

Tucum extract showed in a dose-dependent way a protection effect for menadione $15 \mu \mathrm{M}$ in wild type and mutant yeast colony viability (Fig. 4). In a different way, exposition to $5.0 \mathrm{mM} \mathrm{H}_{2} \mathrm{O}_{2}$ resulted in colony viability recover in BY4741 yeast cells but did not showed the same result for mutant yap $1 \Delta$ strains which maintained low viability even with high tucum extract concentration (Fig. 4).

\section{Discussion}

In our study, S. cerevisiae cells were treated with different compounds, including ethanol, the vehicle used to dissolve menadione. This was done because ethanol can reduce yeast cell viability of yeasts when in high concentrations[18]. Yeast cells BY4741 and yap $1 \Delta$, in the presence of ethanol, grew in a similar way as cells in the presence of YPD medium only. Therefore, we can exclude any ethanol effect in yeasts treated with menadione. 
Previous studies showed that wild type (BY4743 and BY4741) S. cerevisiae have their growth reduced with 1 to $4 \mathrm{mM} \mathrm{H}_{2} \mathrm{O}_{2}$ and $150 \mu \mathrm{M}$ to $0.75 \mathrm{mM}$ menadione[8,19]. Hydrogen peroxide can reduce BY4741 yeast colony formation as well, at $2.5 \mathrm{mM}$ concentration[20]. We found that $0.5 \mathrm{mM} \mathrm{H}_{2} \mathrm{O}_{2}$ and $15 \mu \mathrm{M}$ menadione caused a significative reduction in cell grown in both wild (BY4741) and mutant (yap1 $\Delta$ ) $S$. cerevisiae, which indicates that the BY4741 strain is sensitive to lower concentrations of $\mathrm{H}_{2} \mathrm{O}_{2}$ than the concentrations investigated $[8,20,21]$. The yap $1 \Delta$ strain was not investigated in this same context by other authors. The observed increased deleterious effects of the oxidants, $\mathrm{H}_{2} \mathrm{O}_{2}$ and menadione, on yap $1 \Delta$, when compared with its wild type counterpart BY4741, demonstrates the important role of this transcription factor for antioxidant protection.

Secondary plant metabolism compounds have been extensively investigated for their antioxidant potencial. Curcumin, when used at the concentrations of 50 and $150 \mu \mathrm{g} / \mathrm{ml}$, delays $S$. cerevisiae cell growth, without reducing cell density, after 20 hours of exposure[22]. Pomegranate juice $(100 \mu \mathrm{l} / \mathrm{ml})$ increases yeast cell density after 72 hours, but also delay the cell cycle[23]. According to our findings, concentrations of 100 and $150 \mu \mathrm{g} / \mathrm{ml}$ of tucum-do-cerrado aqueous extract had similar effects on BY4741 and yap $1 \Delta$ yeast strains, indicating that some tucum-do-cerrado compounds may delay cell growth progression without causing cell death. A propolis alcoholic extract was shown to be nontoxic to wild type $S$. cerevisiae at the concentrations of 50 and $100 \mu \mathrm{g} / \mathrm{ml}$ which is similar to the concentrations we used in our study. Such concentrations were toxic to the mutant yap $1 \Delta$ strain while had no effect on the wild type yeast strain.[24].

Some foods rich in polyphenols have been shown to maintain normal cell growth even when cells are stressed with $\mathrm{H}_{2} \mathrm{O}_{2}$ or menadione[19,22,23]. In the same experimental condition, tucum extract was effective on improve cell growth on wild $S$. cerevisiae in concentrations such as 10,25 and $50 \mu \mathrm{g} / \mathrm{ml}$. The higher concentrations $(100$ and $150 \mu \mathrm{g} / \mathrm{ml}$ ) also improved cell growth but delayed cell growth progression and maintained cell density slight lower than control group. Moreover, tucum extract was not able to increase cell growth on mutant stressed cells from $S$. cerevisiae, suggesting that YAP1 gene expression may be involved in protection mechanism on this strain.

Table 1 is a summary of the main results obtained in this study. In the experiments made in liquid medium, tucum extract showed no protection from the action of both, $\mathrm{H}_{2} \mathrm{O}_{2}$ and menadione in the mutant yeast strain, but restored growth to the level in the absence of the oxidants in the wild type strain. Regarding the results in solid medium, the tucum extract showed partial protection from the action of menadione in the mutant and in the wild type strain. Protection against $\mathrm{H}_{2} \mathrm{O}_{2}$ is non-existent in the mutant and partial in the wild type. This indicates that tucum protection against $\mathrm{H}_{2} \mathrm{O}_{2}$ is dependent on YAP1, but not in the case of menadione. 
Table 1

Effects of tucum-do-cerrado extract on growth and cell viability of wild type (BY4741) and mutant $($ yap1 $\Delta)$ Saccaromyces cerevisiae strains.

\begin{tabular}{|c|c|c|c|c|c|c|c|c|}
\hline Medium & Liquid & & & & Solid & & & \\
\hline \multirow[t]{2}{*}{ Tucum $(\mu \mathrm{g})$} & \multicolumn{2}{|c|}{$1 \mathrm{mMH}_{2} \mathrm{O}_{2}$} & \multicolumn{2}{|c|}{15 uMMD } & \multicolumn{2}{|c|}{$1 \mathrm{mM} \mathrm{H}_{2} \mathrm{O}_{2}$} & \multicolumn{2}{|c|}{15 uMMD } \\
\hline & BY4741 & yap1 $\Delta$ & BY4741 & yap $1 \Delta$ & BY4741 & yap $1 \Delta$ & BY4741 & yap1 $1 \Delta$ \\
\hline 50 & +++ & 0 & +++ & 0 & n.d. & n.d. & n.d. & n.d. \\
\hline 100 & $+++\star$ & 0 & $+++\star$ & 0 & ++ & 0 & ++ & + \\
\hline 150 & $+++*$ & 0 & $+++\star$ & 0 & + & 0 & +++ & +++ \\
\hline
\end{tabular}

Saccharomyces cerevisiae has different responses to stress caused by menadione and $\mathrm{H}_{2} \mathrm{O}_{2}[25,26]$. The antioxidant response of these cells is adapted to react to different levels of hydrogen peroxide by activating expression of genes coding for antioxidant enzymes such as SOD1 and SOD2 that are targeted by YAP1 $[5,27]$. Menadione can increase superoxide and $\mathrm{H}_{2} \mathrm{O}_{2}$ concentrations[28] in the mutant strain, therefore the protection afforded by tucum extract in menadione stressed cells, is probably partially through an YAP1 independent pathway.

\section{Declarations}

\section{ACKNOWLEGEMENTS}

We thank Professor Marcos Dias Pereira for yap1D yeast strain and Professors Daniel Carneiro Moreira and Lidia Maria Pepe de Moraes for reading and suggestions to text manuscript.

\section{Author contributions:}

Study concept and design: Élida Geralda Campos, Renata Cristina da Silva; acquisition of data: Renata Cristina da Silva; analysis and interpretation of data: Renata Cristina da Silva and Élida Geralda Campos; drafting of the manuscript: Renata Cristina da Silva and Élida Geralda Campos; statistical analysis: Renata Cristina da Silva; obtained funding: Renata Cristina da Silva; contributed reagents/materials/analysis tools: Marcos Dias Pereira; study supervision: Élida Geralda Campos. Authors contributed equally to this work.

\section{Conflict of Interest Statement:}


The authors certify that they have NO affiliations with or involvement in any organization or entity with any financial or non-financial interest in the subject matter or materials described in this manuscript.

\section{Funding:}

Renata Cristina da Silva was supported by CAPES (Coordenação de Aperfeiçoamento de Pessoal de Nível Superior).

\section{Ethics declaration:}

This study had no ethical approval required. Additionally, each of the authors confirms that this manuscript has not been previously published and is not under consideration by any other journal.

\section{Data availability:}

All data generated or analysed during this study are included in this manuscript.

\section{Declarations of interest:}

none.

\section{References}

1. Jamieson DJ. Oxidative stress responses of the yeast Saccharomyces cerevisiae. Yeast 1998;14:1511-27. https://doi.org/10.1002/(SICI)1097-0061(199812)14:16<1511::AIDYEA356>3.0.CO;2-S.

2. Auesukaree $C$. Molecular mechanisms of the yeast adaptive response and tolerance to stresses encountered during ethanol fermentation. J Biosci Bioeng 2017;124:133-42. https://doi.org/10.1016/j.jbiosc.2017.03.009.

3. Herrero, E.; Ros, J.; Bellí, G.; Cabiscol E. Redox control and oxidative stress in yeast cells. Biochim Biophys Acta 2008:1217-1235. https://doi.org/10.1016/j.bbagen.2007.12.004.

4. Lushchak VI. Free radicals, reactive oxygen species, oxidative stress and its classification. Chem Biol Interact 2014;224:164-75. https://doi.org/10.1016/j.cbi.2014.10.016.

5. Rodrigues-Pousada, Claudina. Menezes, Regina A. Pimentel C. The Yap family and its role in stress response Claudina. Yeast 2010;27:245-58. https://doi.org/10.1002/yea.1752.

6. Yan C, Lee LH, Davis LI. Crm1p mediates regulated nuclear export of a yeast AP-1-like transcription factor. EMBO J 1998;17:7416-29. https://doi.org/10.1093/emboj/17.24.7416. 
7. Delaunay, Agnès; Pflieger, Delphine; Barrault, Marie-Benedicte; Vinh, Joelle; Toledano MB. A Thiol Peroxidase Is an H2O2 Receptor and Redox-Transducer in Gene Activation. Cell 2002;11:471-481. https://doi.org/10.1038/ni0108-15.

8. Wu MJ, O'Doherty PJ, Fernandez HR, Lyons V, Rogers PJ, Dawes IW, et al. An antioxidant screening assay based on oxidant-induced growth arrest in Saccharomyces cerevisiae. FEMS Yeast Res 2011;11:379-87. https://doi.org/10.1111/j.1567-1364.2011.00726.x.

9. Hassan GS. Menadione. vol. 38. 2013. https://doi.org/10.1016/B978-0-12-407691-4.00006-X.

10. Kim IS, Sohn HY, Jin I. Adaptive stress response to menadione-induced oxidative stress in Saccharomyces cerevisiae KNU5377. J Microbiol 2011;49:816-23. https://doi.org/10.1007/s12275011-1154-6.

11. Fustinoni-Reis AM, Arruda SF, Dourado LPS, da Cunha MSB, Siqueira EMA. Tucum-do-cerrado (Bactris setosa mart.) consumption modulates iron homeostasis and prevents iron-induced oxidative stress in the Rat Liver. Nutrients 2016;8. https://doi.org/10.3390/nu8020038.

12. Rosa FR, Arruda AF, Siqueira EMA, Arruda SF. Phytochemical compounds and antioxidant capacity of tucum-do-cerrado (Bactris setosa mart), Brazil's native fruit. Nutrients 2016;8. https://doi.org/10.3390/nu8030110.

13. Boeing JS, Ribeiro D, Chisté RC, Visentainer JV, Costa VM, Freitas M, et al. Chemical characterization and protective effect of the Bactris setosa Mart. fruit against oxidative/nitrosative stress. Food Chem 2017;220:427-37. https://doi.org/10.1016/j.foodchem.2016.09.188.

14. de Siqueira EMA, Rosa FR, Fustinoni AM, de Sant'Ana LP, Arruda SF. Brazilian Savanna Fruits Contain Higher Bioactive Compounds Content and Higher Antioxidant Activity Relative to the Conventional Red Delicious Apple. PLoS One 2013;8:2-8. https://doi.org/10.1371/journal.pone.0072826.

15. Heibel AB, da Cunha M de SB, Ferraz CTS, Arruda SF. Tucum-do-cerrado (Bactris setosa Mart.) may enhance hepatic glucose response by suppressing gluconeogenesis and upregulating Slc2a2 via AMPK pathway, even in a moderate iron supplementation condition. Food Res Int 2018;113:433-42. https://doi.org/10.1016/j.foodres.2018.07.032.

16. Barreto da Cunha M de S, Arruda SF. Tucum-do-cerrado (Bactris setosa Mart.) may promote antiaging effect by upregulating SIRT1-Nrf2 pathway and attenuating oxidative stress and inflammation. Nutrients 2017;9. https://doi.org/10.3390/nu9111243.

17. Mariani D, Mathias CJ, da Silva CG, Herdeiro R da S, Pereira R, Panek AD, et al. Involvement of glutathione transferases, $\mathrm{Gtt} 1$ and $\mathrm{Gtt} 2$, with oxidative stress response generated by $\mathrm{H}_{2} \mathrm{O}_{2}$ during growth of Saccharomyces cerevisiae. Redox Rep 2008;13:246-54. https://doi.org/10.1179/135100008X309028.

18. Weber FJ, Bont JAM De. Adaptation mechanisms of microorganisms to the toxic effects of organic solvents on membranes. Biochim Biophys Acta 1996;1286:225-45. https://doi.org/http://dx.doi.org/10.1016/S0304-4157(96)00010-X.

19. Peláez-Soto A, Fernández-Espinar MT, Roig P, Gil JV. Evaluation of the Ability of Polyphenol Extracts of Cocoa and Red Grape to Promote the Antioxidant Response in Yeast Using a Rapid Multiwell 
Assay. J Food Sci 2017;82:324-32. https://doi.org/10.1111/1750-3841.13602.

20. Dani C, Bonatto D, Salvador M, Pereira MD, Henriques JAP, Eleutherio E. Antioxidant protection of resveratrol and catechin in Saccharomyces cerevisiae. J Agric Food Chem 2008;56:4268-72. https://doi.org/10.1021/jf800752s.

21. Peláez-Soto A, Fernández-Espinar MT, Roig P, Gil JV. Evaluation of the Ability of Polyphenol Extracts of Cocoa and Red Grape to Promote the Antioxidant Response in Yeast Using a Rapid Multiwell Assay. J Food Sci 2017;82:324-32. https://doi.org/10.1111/1750-3841.13602.

22. Minear S, O'Donnell AF, Ballew A, Giaever G, Nislow C, Stearns T, et al. Curcumin inhibits growth of saccharomyces cerevisiae through iron chelation. Eukaryot Cell 2011;10:1574-81. https://doi.org/10.1128/EC.05163-11.

23. Aslan A, Can MI, Boydak D. Anti-oxidant effects of pomegranate juice on Saccharomyces cerevisiae cell growth. Afr J Tradit Complement Altern Med 2014;11:14-8.

24. de Sá RA, de Castro FA V, Eleutherio ECA, de Souza RM, da Silva JFM, Pereira MD. Brazilian propolis protects saccharomyces cerevisiae cells against oxidative stress. Brazilian J Microbiol 2013;44:9931000. https://doi.org/10.1590/S1517-83822013000300050.

25. Jamieson DJ. Saccharomyces cerevisiae has distinct adaptive responses to both hydrogen peroxide and menadione. J Bacteriol 1992;174:6678-81. https://doi.org/10.1128/jb.174.20.6678-6681.1992.

26. Cuinica LG. Estresse oxidativo induzido por peróxido de hidrogênio e menadiona em células de Saccharomyces cerevisiae BY4741 2019;2019:39-46.

27. Lushchak VI. Adaptive response to oxidative stress: Bacteria, fungi, plants and animals. Comp Biochem Physiol - C Toxicol Pharmacol 2011;153:175-90.

https://doi.org/10.1016/j.cbpc.2010.10.004.

28. Hassan GS. Menadione. vol. 38. 2013. https://doi.org/10.1016/B978-0-12-407691-4.00006-X.

\section{Figures}


Figure 1
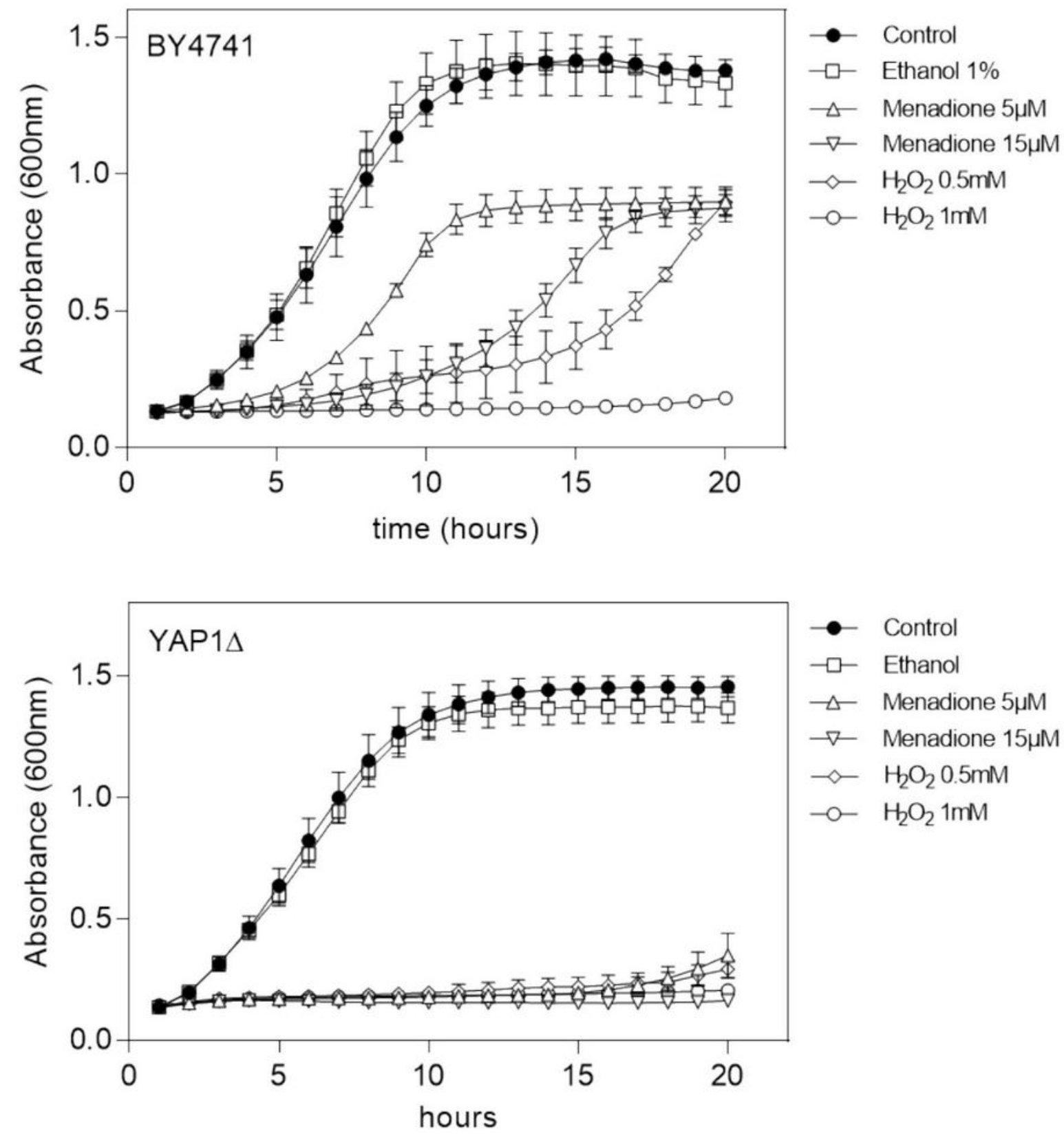

Figure 1

Growth curves of S. cerevisiae strains (BY4741 and yap1 $\Delta$ ) exposed to ethanol $1 \%$, menadione $(5 \mu \mathrm{M}$ and $15 \mu \mathrm{M})$ and $\mathrm{H} 2 \mathrm{O} 2(0.5 \mathrm{mM}$ and $1 \mathrm{mM})$. Error bars indicate the standard error of the mean $(n=3)$ of three different experiments. 
Figure 2
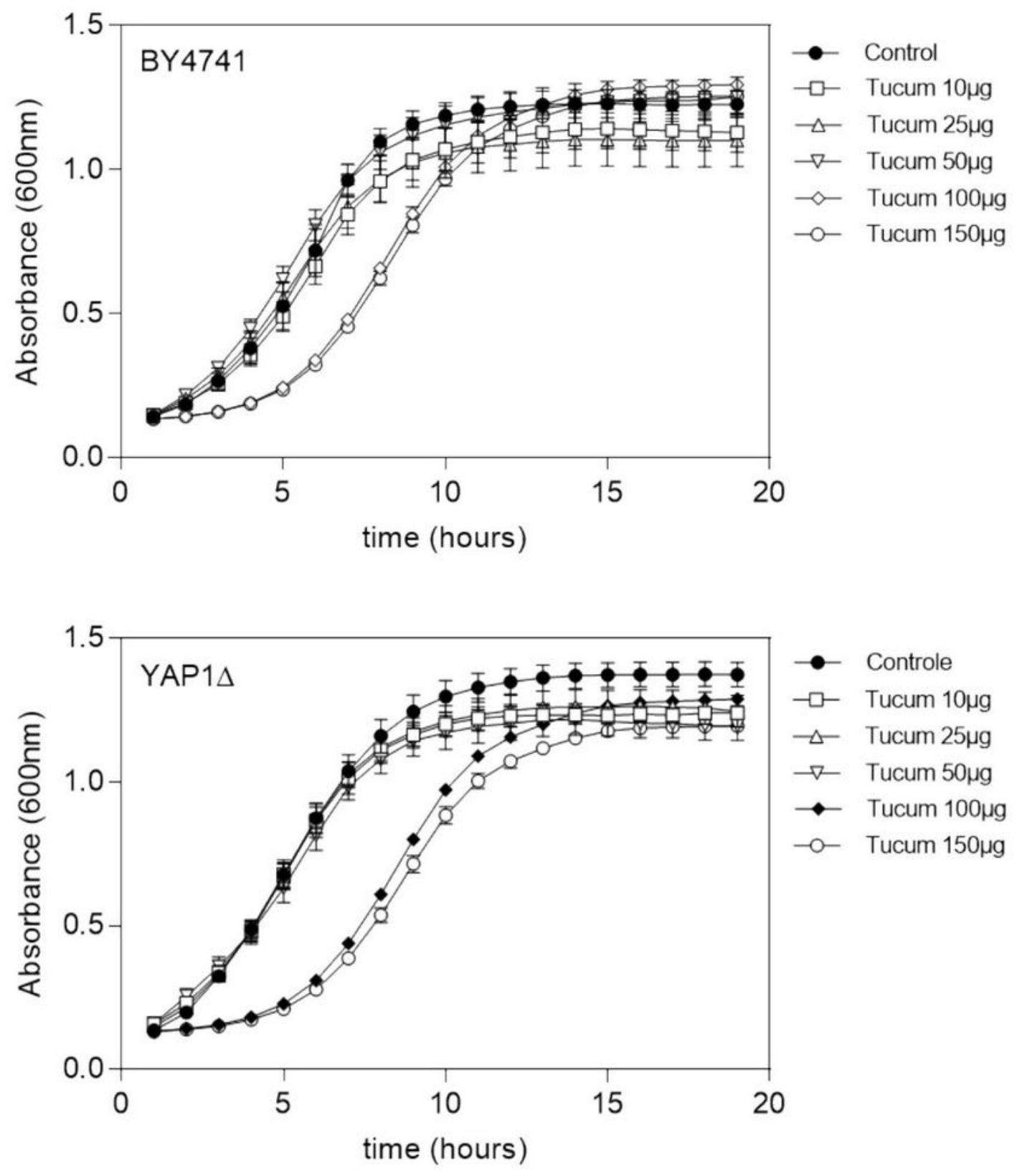

Figure 2

Effect of different concentrations of tucum's aqueous extract $(10,25,50,100$ and $150 \mu \mathrm{g} / \mathrm{ml})$ in S. cerevisiae strains (BY4741 and yap1 $\Delta$ ) growth curves. Error bars indicate the standard error of the mean $(n=3)$ of three different experiments. 
Figure 3
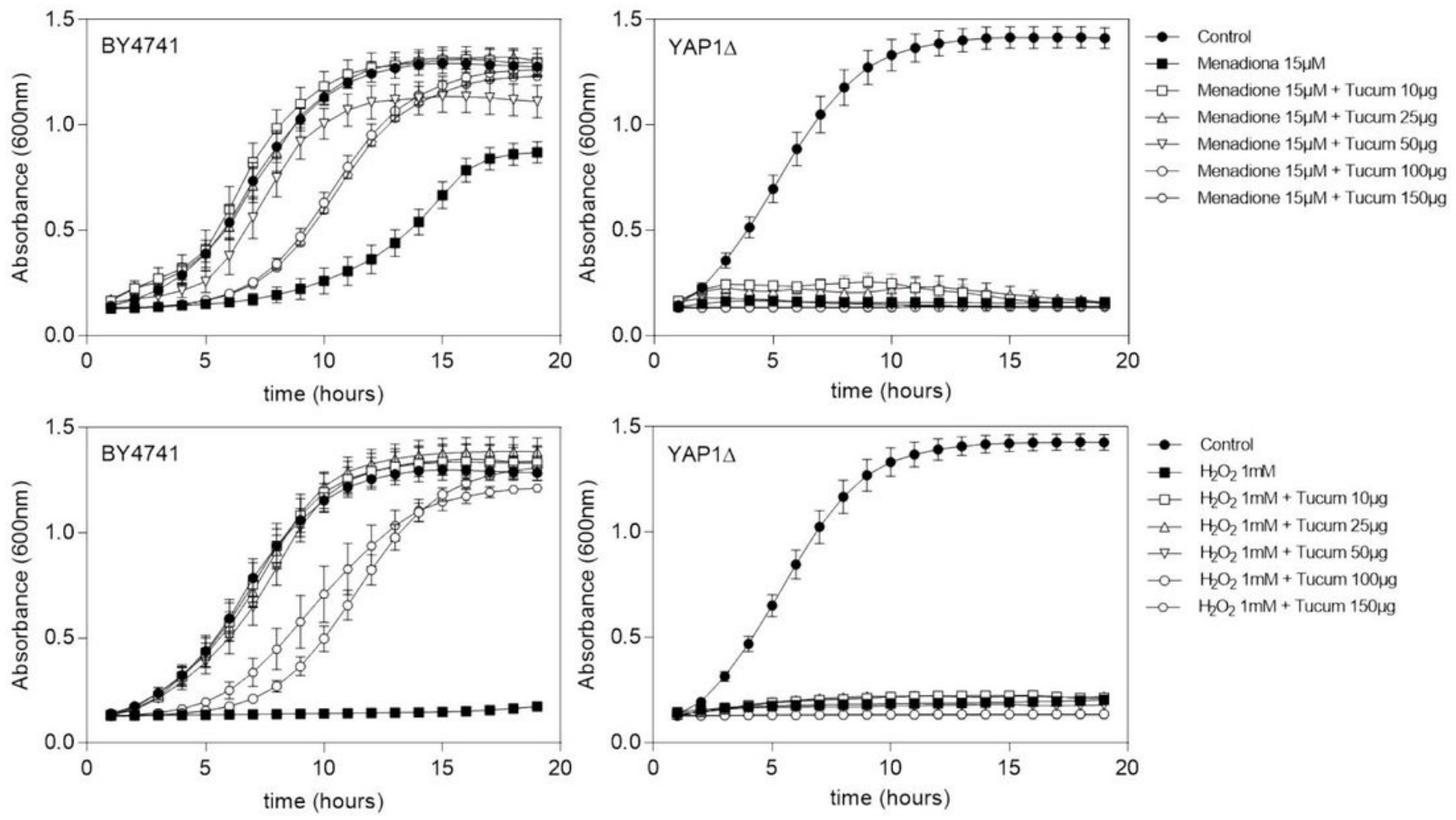

\section{Figure 3}

Effect on growth curves of different concentrations of tucum's aqueous extract in S. cerevisiae strains (BY4741 and yap1 $\Delta$ ) only with YPD medium (C) or exposed to menadione $(15 \mu \mathrm{M})(\mathrm{M}), \mathrm{H} 2 \mathrm{O} 2(1 \mathrm{mM})(\mathrm{H})$, tucum extract $50 \mu \mathrm{g} / \mathrm{ml}(\mathrm{MT} 1)$ or $150 \mu \mathrm{g} / \mathrm{ml}(\mathrm{MT} 2)$ and menadione $(15 \mu \mathrm{M})$, tucum extract $50 \mu \mathrm{g} / \mathrm{ml}(\mathrm{HT} 1)$ or $150 \mu \mathrm{g} / \mathrm{ml}(\mathrm{HT} 2)$ and $1 \mathrm{mM}$ of H2O2. Error bars indicate the standard error of the mean $(\mathrm{n}=3)$ of three different experiments. 
Figure 4
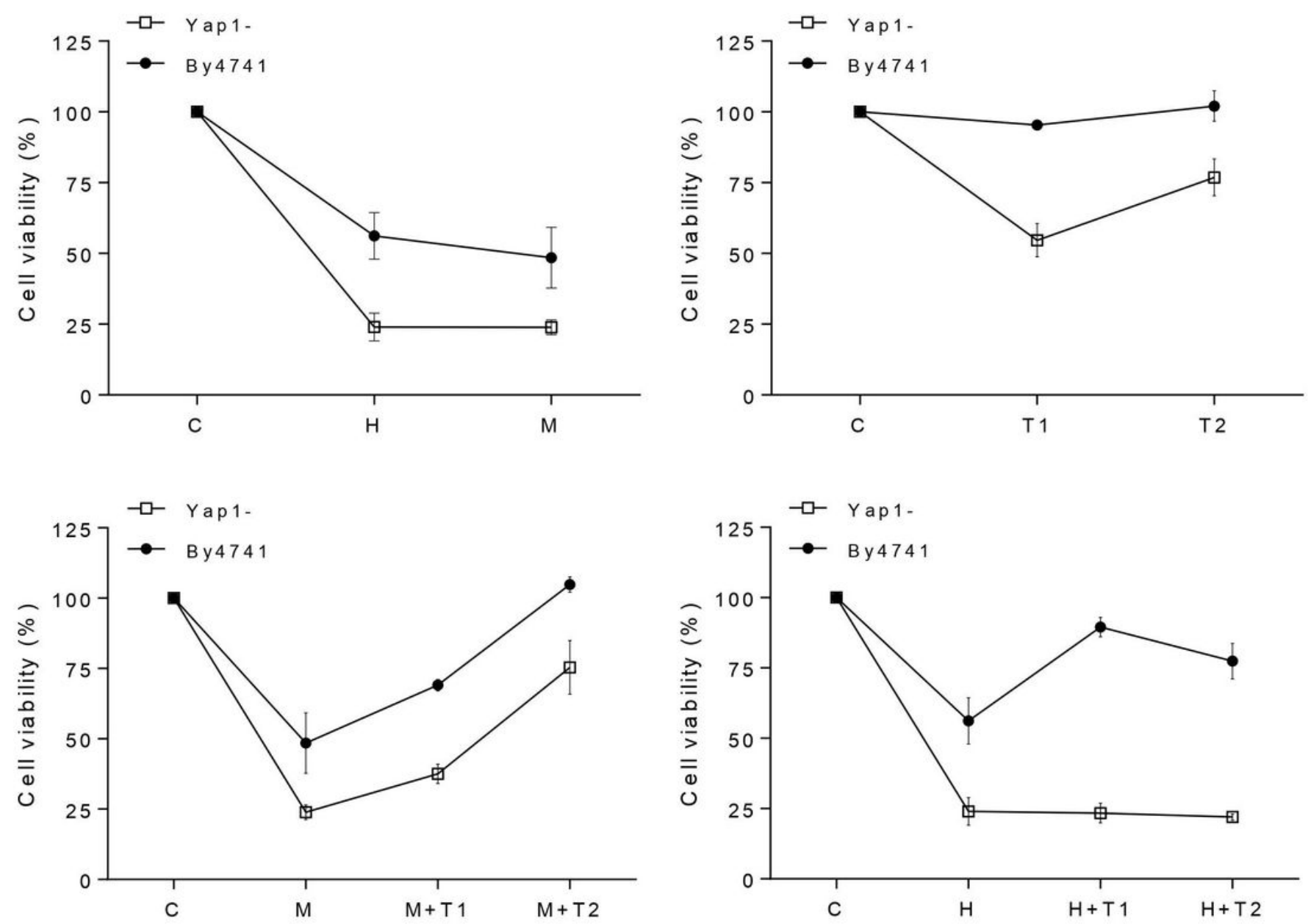

Figure 4

Colony viability of S. cerevisiae strains BY4741 and yap1 $\Delta$ only with YPD medium (C) or exposed to menadione $(5 \mu \mathrm{M})(\mathrm{M}), \mathrm{H} 2 \mathrm{O} 2(0.5 \mathrm{mM})(\mathrm{H}), 50 \mu \mathrm{g} / \mathrm{ml}(\mathrm{T} 1)$ or $150 \mu \mathrm{g} / \mathrm{ml}(\mathrm{T} 2)$ of tucum's extract, pretreated with $50 \mu \mathrm{g} / \mathrm{ml}(\mathrm{MT} 1)$ or $150 \mu \mathrm{g} / \mathrm{ml}$ (MT2) of tucum extract before menadione induced stress and with $50 \mu \mathrm{g} / \mathrm{ml}(\mathrm{HT} 1)$ or $150 \mu \mathrm{g} / \mathrm{ml}(\mathrm{HT} 2)$ of tucum extract before $\mathrm{H} 2 \mathrm{O} 2$ induced stress. Error bars indicate the standard error of the mean $(n=3)$ of three different experiments. 